\title{
PRESENTACIÓN DE ESTE NÚMERO
}

La Revista Sharq al-Andalus. Estudios Árabes inicia una nueva singladura con un giro de timón de algunos grados. Nacida en 1984 como revista arabística, en un momento de crisis en las publicaciones periódicas del arabismo español, hoy plenamente superada, ha realizado un viaje de diez volúmenes que dieron acogida a los muchos y diversos temas científicos que pueden tratarse sobre el mundo árabe $e$ islámico, con especial dedicación a los que se referían a la costa este de la Península Ibérica, el Sharq al-Andalus, desde la conquista musulmana hasta nuestros días.

El nacimiento, desarrollo y multiplicación de otras revistas científicas arabísticas en estos años nos llevó a replantearnos la orientación de la revista a fin de evitar que el público lector de estas revistas, no muy numeroso, encontrase siempre la misma revista, aunque con diferente nombre. Y así, como una de nuestras secciones más apreciadas por el equipo editor, entre los cuales se hayan primeras espadas sobre el tema, era el de mudéjares y moriscos, decidimos especializar la revista sobre este particular. La reciente creación del Centro de Estudios Mudéjares del Instituto de Estudios Turolenses de Teruel indicaba la entidad de los estudios sobre la minoría islámica hispánica, tanto más cuanto el C.E.M. introducía también en su campo a los moriscos, los conversos musulmanes del siglo XVI. Ofrecimos al C.E.M. aragonés la co-edición de la revista y encontramos una respuesta entusiasta. De ahí que haya nacido este número XII de Sharq al-Andalus que se subtitula ahora de Estudios Mudéjares y Moriscos y que editan el Centro de Estudios Mudéjares de Teruel y el Área de Estudios Árabes e Islámicos de la Universidad de Alicante. Sus secciones son una extensión de lo que ya ofrecía la antigua revista: una sección para los "mudéjares", otra para los "moris$\cos ^{\prime}$, otra titulada "textos y contextos" que tratará de la literatura aljamiada, de la morisca en sus diversas lenguas (árabe y español fundamentalmente) y de la literatura española en relación con los mudéjares y moriscos. La cuarta "sección" es novedosa pues tratará sobre el "Arte Mudéjar", que no tenía revista especializada, a pesar de la labor pionera en este campo científico del Instituto de Estudios Turolenses. Finalmente hay una varia, titulada "Notas" y una amplia sección bibliográfica, continuación de una fecunda tarea realizada por algunos de los miembros del equipo alicantino.

Aunque los editores de la revista están convencidos de la entidad de esta línea de investigación, hay algunos investigadores que opinan que la minoría musulmana hispánica o mudéjares y los conversos musulmanes o moriscos no ofrecen materia suficiente de estudio para una especialización, es decir, que la marginación persigue hasta nuestros días a los marginados de otras épocas. El estudio de mudéjares y moriscos no es marginal: es interdisciplinar, que no es lo mismo precisamente, y para probarlo convocamos un "Coloquio" en la Universidad de Alicante, "La Voz de Mudéjares y 
Moriscos", que celebramos del 29 al 31 de marzo de 1995. El eco de la convocatoria en la sociedad científica humanística fue extraordinario, superando nuestras esperanzas, y del interés y calidad de las intervenciones da fe este número donde se publican las ponencias del Coloquio, no formando parte del mismo solamente las secciones "Arte Múdejar", "Notas" y "Bibliografía".

Sharq al-Andalus. Estudios Mudéjares y Moriscos es, por tanto, una revista interdisciplinar abierta a medievalistas, historiadores de la literatura, filólogos, historiadores de la Edad Moderna, historiadores del Arte, arabistas y otros investigadores que se dediquen a estos musulmanes hispánicos sobre los que creemos y sabemos que aún hay mucho que decir. Esta introducción es también una invitación a todos ellos para que colaboren en esta nueva etapa de la revista.

María Jesús RuBIERA MATA 